\title{
PERTANGgUNGJAWABAN PIDANA TERHADAP PELAKU PENJUALAN DAGING ANJING DITINJAU DARI UNDANG-UNDANG NOMOR 8 TAHUN 1999
}

\author{
I Made Bramastra De Putra, I Nyoman Gede Sugiartha \& I Putu Gede Seputra \\ Fakultas Hukum Universitas Warmadewa, Denpasar-Bali, Indonesia \\ debramastra21@gmail.com, nyomansugiartha14@gmail.com, gamyongputu@gmail.com
}

\begin{abstract}
Abstrak
Anjing merupakan salah satu hewan peliharaan favorit dan banyak dicintai, namun hal tersebut tidak menghalangi adanya praktik penjualan daging anjing secara ilegal sebagai bahan campuran makanan. Mengingat penjualan illegal daging anjing belum ada sanksi pidana yang jelas dari pemerintah maka peneliti ini bertujuan untuk mengkaji bentuk pertanggungjawaban pelaku penjualan daging anjing dilihat dari perspektif perlindungan konsumen dan sanksi pidana bagi pelaku berdasarkan undang-undang. Penelitian ini dilakukan dengan metode hukum normatif di mana menggunakan pendekatan konseptual dan pendekatan perundang-undangan. Dari hasil temuan, maka dapat ditarik simpulan bahwa pelaku harus bertanggungjawab terhadap konsumen berdasarkan Undang-Undang Perlindungan Konsumen Pasal 4 huruf a yang menjamin keselamatan, kenyamanan, dan keamanan konsumsi barang dan/atau jasa, dan pelaku dapat dikenakan sanksi denda maksimal dua miliar rupiah atau kurungan maksimal lima tahun karena melanggar ketentuan dalam pasal 8 pada undang-undang perlindungan konsumen pasal 62 ayat 1 . Kata kunci: Daging Anjing, Hukum Pidana, Pertanggungjawaban.
\end{abstract}

\begin{abstract}
Dogs are one of the favorite and much-loved pets, but this does not prevent the illegal sale of dog meat as a food ingredient. Considering that there is no clear criminal sanction from the illegal sale of dog meat from the government, the research aims to examine the accountability of the perpetrators of selling dog meat from a consumer protection perspective and the criminal sanction for the perpetrator based on law. This research was conducted with a normative method with conceptual approach and statutory approach. From the result the researcher found that the perpetrator must be responsible to consumers based on the Consumer Protection Law Article 4 letter a, which guarantees the safety, comfort and security of consumption of goods and / or services, and the perpetrator may be subject to a maximum fine of 2 billion rupiah or a maximum imprisonment of 5 years for violating the provisions in Article 8 based on the consumer protection law article 62 paragraph 1.
\end{abstract}

Keywords: Dog Meat, Criminal Law, Liability

\section{PENDAhuluan}

Penjualan daging anjing merupakan masalah bila dikaitkan dengan Undang-Undang Perlindungan Konsumen, disini penjualan olahan makanan daging anjing ini dicampur dengan olahan makanan lainnya, sehingga konsumen tidak mengetahuinya. Praktik ini subur terjadi karena daging anjing illegal dijual dipasaran dengan harga yang relatif murah. Namun, perlu disadari bahwa konsumen memiliki hak-hak yang terlindungi secara hukum dalam undangundang perlindungan konsumen No.08/1999 atas keamanan, kenyamanan dan keselamatan terhadap produk dan jasa serta memiliki kebebasan memilih barang atau jasa sesuai kualitas yang ditawarkan. Kemudian, konsumen juga berhak mendapatkan servis yang jujur dan berimbang serta hak atas ganti rugi barang atau jasa yang tidak sesuai dengan penawaran dan lainnya.

Perihal adanya penjualan daging anjing selama ini belum ditanggapi serius oleh aparat penegak hukum, padahal video pelaku penjual daging anjing ini sering beredar di media sosial terutama pada saat pelaku membunuh dan mengolah daging anjing tersebut. Beberapa hal yang 
menyebabkan pelaku tidak dilaporkan ke aparat penegak hukum adalah karena tidak adanya bukti dari perbuatan yang dilakukan, atau hanya adanya percobaan yang mana hal itu tidak masuk kedalam tindak pidana (pidana yang tidak sempurna) dan tidak bisa dikenakan sanksi pdana atasnya (Chazawi, 2005).

Konsumsi daging anjing yang dilakukan olah masyarakat di Bali sempat mendapat perhatian dari aktivis hewan hingga pada akhirnya Gubernur Bali mengeluarkan himbauan resmi untuk menghentikan penjualan daging anjing. Himbauan ini juga didasari oleh aspek kesehatan yang tidak terjamin dari mengkonsumsi daging anjing, karena kegiatan mengkonsumsi daging anjing ini bisa meningkatkan penyebaran penyakit zoonosis dan juga penyakit rabies. Anjing termasuk kedalam jenis jewan yang dapat terkena penyakit yang dapat tertular oleh manusia untuk itu, daging anjing dapat dikategorikan sebagai daging yang tidak boleh dikonsumsi (Susanti, 2021). Makanan yang baik untuk dikonsumsi, maksudnya makanan yang tidak berbahaya baik secara fisik maupun intelektual (Thabrani, 2013). Mengkonsumsi daging anjing juga dinilai tidak sesuai dengan hukum keselamatan dan keamanan hewan yang tercantum dalam Undang-Undang No. 18/2009 pasal 66. Kegiatan perdagangan serta konsumsi daging anjing di Bali dinilai tidak sesuai dengan prosesnya, kemungkinan hewan anjing ditangkap dan dibunuh termasuk dengan menggunakan racun yang beresiko terhadap kesehatan manusia.

Penjual daging anjing biasanya akan memasang penanda bertuliskan RW yang merupakan singkatan dari rintek wuuk dalam bahasa Manado yang berarti bulu halus adalah makanan dengan bahan dasar anjing yang jadi makanan wajib dalam pesta pernikahan di Sulawesi Utara. Olahan daging anjing ini sangat mudah juga ditemukan di Kupang, Nusa Tenggara Timur dan beberapa kota serta daerah lainnya di Indonesia dimana hal ini sudah menjadi kebiasaan bahkan kebudayaan warga setempat.

Berkenaan dengan hal ini, pemerintah diharapkan dapat menyusun aturan hukum terkait keselamatan, kesejahteraan, dan keamanan hewan. Dalam Undang-Undang kesejahteraan hewan No.18/2009 pasal 66 dicantumkan, berkenaan dengan kesehatan dan peternakan hewan, lima prinsip dasar kebebasan satwa menjadi hal fundamental yang harus diperhatikan. Kemudian, masyarakat secara umum juga memiliki tanggungjawab sebagai pendamping pemerintah dalam penegakan aturan berkenaan kesejahteraan hewan yang kemudian dituangkan dalam pasal 67. Hal ini juga bertentangan dengan kehalalan makanan yang akan dikonsumsi, Triasih et al (2016) mengkaji tentang perlindungan hukum bagi konsumen terhadap produk makanan bersertifikat halal. Mengkonsumsi daging anjing berarti kita turut andil dalam perbuatan yang merenggut kesejahteraan hewan peliharaan (Fajar, 2018). Maraknya praktik jual beli daging anjing menarik perhatian para penjual untuk lebih kreatif agar menarik pembeli, misalnya membuat olahan masakan dari daging anjing menjadi rica-rica dan diperjual belikan, hal ini di kaji dalam penelitian (Satriya, 2019). Berdasarkan penjelasan sebelumnya, peneliti memutuskan untuk mengkaji pertanggungjawaban pidana terhadap pelaku penjualan daging anjing, di mana peneliti ini bertujuan untuk mengkaji bentuk pertanggungjawaban pelaku penjualan daging anjing dilihat dari perspektif perlindungan konsumen dan sanksi pidana bagi pelaku berdasarkan undang-undang.

\section{METODE PENELITIAN}

Studi ini merupakan penelitian hukum normatif dimana analisis data dilakukan secara sistematis dengan pendekatan konseptual yang mengacu pada asas hukum dan aturan undang-undang yang ada. Teknik dokumentasi dipakai dalam studi ini sebagai teknik pengumpulan data dengan melibatkan dokumen dan literature lain dengan bahasan terkait perlindungan konsumen. 


\section{HASIL DAN PEMBAHASAN}

\section{Pertanggungjawaban Pelaku Penjual Daging Anjing Dari Sudut Pandang Perlindungan Konsumen}

Dalam pemberian sanksi pertanggungjawaban yang akan diberikan kepada pelaku usaha yang memproduksi daging anjing untuk makanan olahan belum bisa memberikan sanksi karena ketiadaan aturan tegas dari pemerintah. Dengan rencana jangka panjang untuk mengurangi peredaran makanan berbahan daging anjing di Bali, pemerintah hanya memberikan pengertian kepada masyarakat agar mengurangi mengkonsumsi makanan olahan daging anjing dan memberikan kesadaran bahwa anjing bukanlah komoditas yang layak untuk dikonsumsi.

Landasan hukum atas berhaknya konsumen untuk mendapatkan perlindungan hukum tertuang dalam beberapa aturan berikut:

1. UUD 1945 Pasal 27, Pasal 5 ayat (1), Pasal 33, dan Pasal 21 ayat (1).

2. Surat Edaran Dirjen Perdagangan Dalam Negeri No.235/DJPDN/VII/2001 tentang Penanganan Pengaduan Konsumen yang ditujukan kepada seluruh Dinas Indag Prop/Kab/Kota.

3. PP No.58/2001 tentang Pembinaan Pengawasan dan Penyelenggaran Perlindungan Konsumen.

4. UU Perlindungan Konsumen No.8/1999 (Lembaran Negara Republik Indonesia tahun 1999 No. 42 tambahan Lembaran Negara Republik Indonesia No. 3821)

5. UU No.30/1999 tentang Arbitrase dan Alternatif Penyelesaian Sengketa.

6. Surat Edaran Direktur Jendral Perdagangan Dalam Negeri No. 795/DJPDN/SE/12/2005 tentang Pedoman Pelayanan Pengaduan Konsumen.

Dibentuknya UUPK disebabkan oleh beberapa clausula pertimbangan sebab regulasi yang menjamin perlindungan atas hak-hak konsumen di Indonesia belum maksimal, sehingga menjadi penting untuk membuat perangkat regulasi hukum dalam rangka memaksimalkan keseimbangan perlindungan hak konsumen dan pelaku usaha demi tercipta dan jalannya stabilitas perekonomian yang sehat. Dengan adanya kondisi seperti ini, sudah pasti dunia usaha akan tumbuh serta melahirkan beragam produk dan jasa yang mampu bersaing secara global guna meningkatkan kesejahteraan masayarakat dan mendorong pembangunan ekonomi nasional (Widjaja dan Yani, 2003). Norma-norma terhadap penjamina hak-hak konsumen yang diatur dalam UUPK merupakan UU payung yang dijadikan sebagai dasar putusan apabila terdapat dugaan praktik kecurangan terhadap hak konsumen dan diharapkan bisa menjadi jalan penyelesaian apabila terjadi suatu masalah dalam isu terkait. Namun dalam praktik pelaksanaannya, bahkan sampai tahap litigasi, aturan tersebut belum mampu memberikan kepastian hukum bagi konsumen yang dirugikan.

Pada dasarnya, UUPK menempatkan dan menjamin kesetaraan hukum antara pelaku usaha dan konsumen. Namun, dalam pelaksanaan dan penerapan aturan ini harus ada pengawasan dan pengawalan demi terciptanya hubungan yang setara dan berimbang antara konsumen dengan pelaku usaha dalam kegiatan ekonomi supaya tidak ada pihak yang dirugikan karena ada payung hukum yang menjamin perlindungan atas hak-hak yang menjadi kepemilikian kedua belah pihak (Nugroho, 2011)

Pelaku usaha adalah lembaga atau individu yang memproduksi, menawarkan, menjual, ataupun mendistribusikan produk barang atau jasa sesuai dengan kemampuan dan keahlian kepada khalayak luas. Kesemua bentuk kegiatan diatas merupakan hak yang dijamin dalam hukum bagi para pelaku usaha. Pelaku usaha yang dikatakan menjalankan hak dan kewajibannya dengan benar adalah mereka yang jujur dan memberikan edukasi, sosialisai terhadap informasi produk yang ditawarkan secara benar, objektif dan tidak menipu. Kejujuran yang dimaksud juga termasuk didalamnya memproduksi barang layak pakai dan layak guna dengan kualitas yang sesuai dengan standar yang berlaku agar konsumen bisa mengonsumsi barang/jasa sebagaimana harapan dan keinginan mereka. Namun, dalam kasus penelitian ini, 
pihak pelaku usaha yang menjual daging anjing secara ilegal dengan cara mencampurkannya dalam bahan makanan bukanlah pelaku usaha yang jujur dan dapat dipercaya karena dalam praktik penjualan mereka melakukan unsur penipuan dengan menjual makanan olahan yang tidak layak konsumsi.

Berdasarkan asas perlindungan konsumen bahwa dalam hal ini dalam perlindungan hakhak konsumen, konsumen memiliki hak-hak yang harus dilindungi baik dalam hal keamanan dan keselamatan konsumen dimana seharusnya konsumen atau masyarakat tidak memiliki keraguan dalam mengkonsumsi daging yang beredar di pasaran serta daging tersebut layak untuk diperjual belikan.

Berkembangnya jasa kuliner yang menyajikan makanan olahan dengan dicampurnya daging anjing dengan makanan olahan lainnya di Bali tidak terlepas karena dorongan kebutuhan masyarakat yang gemar terhadap kuliner tersebut. Mitos di masyarakat bahwa daging anjing mempunyai banyak khasiat bagi tubuh diantaranya bisa menyembuhkan beberapa penyakit, tidak terkecuali yang berkaitan dengan syahwat dan vitalitas, menyebabkan produk makanan olahan ini banyak dicari masyarakat. Di lain sisi anjing bukanlah komoditas yang lazim untuk dikonsumsi, karena alasan juga belum adanya jaminan kesehatan bagi konsumennya. Sebenarnya tidak hanya dari sisi konsumen saja yang mesti mendapatkan perlindungan tetapi juga bagi masyarakat secara umum yang bukan bagian dari konsumen.

Berdasarkan UUPK, kegiatan penjualan daging anjing secara ilegal dipasaran serta praktik pencampuran bahan makanan dan makanan olahan dengan daging anjing yang berotensi menularkan penyakit kepada konsumen oleh pelaku usaha merupakan sebuah tindakan pelanggaran terhadap hak-hak yang melekat pada konsumen selaku pengguna dan penikmat barang dan/atau jasa yang ditawarkan. Beberapa pasal yang dilanggar dalam UUPK oleh pelaku usaha yang menjual dan mencampur daging anjing dalam makanan olahan adalah sebagai berikut:

1. Dalam tindakannya menjual dan mencampurkan daging anjing dalam olahan makanan yang sebenarnya tidak layak dikonsumsi karena bepotensi menularkan rabies kepada konsumen selaku pengguna dan penikmat produk, pelaku usaha telah melakukan pelanggaran terhadap Pasal 4 huruf a tentang perlindungan hak konsumen untuk mendapatkan keselemanatan, keamanan, serta kenyamanan dalam mengonsumsi barang dan jasa mendapatkan kenyamanan, keamanan, dan keselamatan dalam mengkonsumsi barang dan/atau jasa.

2. Tindakan pencampuran bahan makanan dengan daging anjing oleh pelaku dengan tanpa sepengetahuan konsumen dan ketiadaan informasi yang diberikan oleh pelaku usaha kepada konsumen merupakan tindakan tidak jujur dan mengandung unsur penipuan serta pelanggaran hak konsumen yang diatur dalam Pasal 7 huruf b. Secara umum, tuntutan ganti kerugian atas kerugian yang dialami oleh konsumen sebagai akibat penggunaan barang dan/atau jasa, baik yang berupa kerugian materi, fisik maupun jiwa, dapat didasarkan pada beberapa ketentuan yaitu tuntutan ganti kerugian berdasarkan wanprestasi dan tuntutan ganti kerugian berdasarkan perbuatan melanggar hukum.

\section{Sanksi Pidana Terhadap Pelaku Penjualan Daging Anjing Dalam Kitab Undang- Undang Hukum Pidana}

Dilihat dari proses kegiatan yang dilakukan pelaku usaha dalam kasus penelitian ini sanksi pidana sudah sepatutnya dijatuhi kepada mereka yang menjual makanan olahan bercampur daging anjing tanpa sepengetahuan konsumen. Karena dalam praktiknya, kegiatan tersebut masuk kedalam ranah penipuan, kecurangan, dan pelanggaran hak konsumen. Pada hakikatnya kerugian yang ditanggung oleh konsumen adalah mendapatkan barang yang tidak sesuai dengan penawaran. Daging anjing yang dicampur dalam olahan makanan tidak termasuk dalam bahan layak konsumsi. Masalah ini sudah diatur dan tercantum dalam Undang-Undang perlindungan 
konsumen No. 8/1999. Dalam aturan yang lebih terperinci, sesuai dengan butir-butir dalam pasal 62 ayat 1, pencampuran makanan dengan daging anjing melanggar pasal 8 butir $\mathrm{f}$, dan terancam hukuman kurungan dan sanksi denda.

Di dalam KUHP ada hukum yang berlaku sebagai dasar penegakan hukum di Indonesia. KUHP itu sendiri merupakan warisan dari kolonial Belanda yang pada kenyataannya masih banyak pengaturan di dalam KUHP yang tidak sesuai dengan kondisi masyarakat Indonesia pada saat ini. Tujuan pemidanaan khususnya bagi pelaku penjualan dan pembunuhan daging anjing diperlukan pengaturan lainnya yang diatur dalam peraturan Perundang-undangan.

Di dalam KUHP itu sendiri hanya ada yang mengatur mengenai tindak pidana penganiayaan terhadap hewan yang tertuang di dalam Pasal 302 KUHP yang menyatakan sebagai berikut:

(1) Penganiayaan ringan yang dilakukan terhadap hewan diancam dengan hukuman penjara paling lama tiga bulan atau hukuman denda paling banyak senilai empat ribu lima ratus rupiah.

(2) Apabila perbuatan tersebut menyebabkan hewan cacat, sakit lebih dari satu minggu, menderita luka berat yang dapat menyebabkan kematian pada hewan, maka yang bersalah dipidana dengan pidana penjara paling lama sembilan bulan atau pidana denda paling banyak senilai tiga ratus rupiah karena penganiayaan hewan.

(3) Apabila hewan tersebut milik yang bersalah, maka hewan tersebut dapat dirampas.

(4) Percobaan dalam hal melakukan kejahatan terhadap hewan tidak dapat dipidana.

Bunyi ayat dari pasal 302 KUHP di atas dapat disimpulkan bahwa:

1. barang siapa dengan tanpa adanya suatu tujuan yang patut atau secara melampaui batas, dengan penuh kesengajaan memberikan luka atau rasa sakit kepada hewan yang dapat merugikan kesehatannya;

2. barang siapa dengan tanpa adanya suatu tujuan yang patut atau secara melampaui batas yang diperlukan untuk mencapai tujuan tersebut atau tanpa tujuan yang patut, dengan penuh kesengajaan tidak memberikan makanan untuk keperluan hidup hewan, yang atau sebagian menjadi kepunyaannya dan ada di bawah pengawasannya kepada hewan yang wajib dipeliharanya.

Ketentuan seperti yang telah dijelaskan di atas dapat dengan mudah digunakan apabila terdapat oknum yang melakukan penjualan dan penganiayaan terhadap anjing yang bahkan menyebabkan kematian bagi anjing itu sendiri. Di dalam buku yang berjudul KUHP yang disertai dengan komentar lengkap pasal demi pasal yang dibuat oleh R. Soesilo menjelaskan bahwa yang dimaksud dalam ayat (1) tersebut adalah penganiayaan ringan pada hewan dalam hal ini anjing. Pasal tersebut dapat dibuktikan dengan:

1) Orang itu dengan kesadaran penuh atau dapat dikatakan dengan sengaja melukai, menyakiti atau merusak kesehatan hewan.

2) Perbuatan itu dilakukan dengan adanya suatu tujuan yang patut atau melewati batas yang diizinkan.

3) Dengan kesadaran penuh atau dapat dikatakan dengan sengaja tidak memberi makan atau minum kepada hewan dengan maksud memberikan penderitaan.

4) Hewan tersebut sama sekali atau sebagian menjadi kepunyaan orang itu atau di dalam penjagaannya atau harus dipeliharanya.

5) Perbuatan tersebut dilakukan tidak dengan maksud dan tujuan yang patut atau melewati batas yang diizinkan (Soesilo, 1995)

Berdasarkan penjelasan dari R. Soesilo tersebut dapat kita ketahui bahwa hewan yang dimaksud di dalam KUHP adalah hewan pada umumnya yang bukan merupakan hewan langka atau hewan yang dilindungi oleh negara. Oleh karena itu anjing termasuk dalam pasal ini. Jadi dapat dikatakan oknum-oknum tertentu yang melakukan penjualan maupun pembunuhan terhadap anjing dengan cara yang keji apalagi hingga menjadikan daging anjing tersebut sebagai 
makanan olahan dapat diancam dengan pidana penjara paling lama 9 bulan atau pidana denda paling banyak 300 Rupiah.

Dari perihal tersebut mengakibatkan konsumen tidak mengetahui daging yang mereka konsumsi. Dengan demikian dapat tergambarkan bahwa dalam permasalahan ini terdapat pelanggaran terhadap hak konsumen yang sudah jelas tertuang di dalam UU No.8 Tahun 1999 tentang Perlindungan Konsumen Pasal 4. Perlindungan bagi konsumen merupakan jaminan yang didapatkan oleh para konsumen dari sebuah produk yang telah diproduksi oleh para pelaku usaha didasarkan pada posisi tawar menawar konsumen yang lemah (Nasution, 2002)

\section{. SIMPULAN DAN SARAN}

\section{Simpulan}

Dari penjelasan hasil penelitian di atas dapat disimpulkan sebagai berikut:

1. Pertanggungjawaban pelaku penjual daging anjing dari perlindungan konsumen tertuang di dalam UU No. 8 Tahun 1999 Tentang Perlindungan Konsumen Pasal 4 huruf a. Pelaku usaha telah melakukan pelanggaran-pelanggaran dalam pembuatan makanan olahan yang bercampur dengan daging anjing tersebut yang dimana merugikan konsumen. Perdagangan daging anjing ini juga bisa menimbulkan suatu penyakit bagi yang mengkonsumsinya misalnya penyakit rabies, pada saat pemotongan hewan kita tidak mengetahui tempat dan kesehatan dari anjing tersebut yang tidak jelas.

2. Sanksi pidana yang di dapat oleh pelaku penjualan daging anjing adalah suatu tindak pidana yang telah melanggar dari ketentuan di dalam UU No. 8 Tahun 1999 Tentang Perlindungan Konsumen pada Pasal 62 ayat 1. Pelaku usaha yang menjual daging anjing dengan cara dicampur dengan daging lainnya, sehingga konsumen tidak mengetahui daging yang mereka konsumsi. Disini pelaku usaha yang menjual daging olahan dengan dicampur dengan daging anjing merupakan suatu hal kelalaian atau kesengajaan yang dilakukan pelaku usaha agar makanan olahan yang dijual tidak diketahui oleh konsumen.

\section{Saran}

Melalui kajian ini, peneliti ingin menyampaikan beberapa saran yang kiranya dapat membantuk pemerintah untuk lebih memperhatikan beberapa hal, sepert:

1. Anjing merupakan sahabat setia dari manusia yang biasanya senantiasa menjaga rumah, seharusnya anjing tidak layak untuk dikonsumsi terlebih dari penyebaran penyakit rabies akibat mengkonsumsi daging anjing. Pemerintah diharapkan untuk membuat regulasi yang jelas agar penjual daging anjing bisa mendapatkan hukuman dan efek jera agar tidak terjadi lagi penjualan dan pembunuhan terhadap anjing.

2. Dengan belum adanya regulasi yang jelas dan kebijakan dari pemerintah, seharusnya pemerintah lebih gencar melaksanakan sosialisasi kepada para pedagang daging agar mereka menjual makanan yang layak untuk di konsumsi dan tidak menjual daging anjing sebagai makanan olahan serta melayani konsumen secara benar dan jujur sebagaimana kewajiban pelaku usaha yang diatur dalam UU No. 8 Tahun 1999 tentang Perlindungan Konsumen Pasal 7.

3. Pemerintah diharapkan agar penjual makanan olahan yang bercampur dengan daging anjing agar mendapatkan sanksi dari suatu Perundang-Undangan dan di pertegas regulasinya, agar pelaku usaha yang menjual daging anjing mendapatkan sanksi yang jelas.

\section{DAFTAR PUSTAKA}

Chazawi, A. (2005). Pelajaran hukum pidana: percobaan dan penyertaan (bagian 3). Raja Grafindo Persada, Jakarta. 
Fajar, K. (2018). Upaya Humane Society International (HSI) Dalam Perlindungan Hewan Anjing dan Kucing di Festival Yulin, China. Jurnal Ilmu Hubungan International, Vol.6.

Nasution, A. (2002). Hukum perlindungan konsumen: suatu pengantar. Diadit Media, Jakarta.

Nugroho, S. A. (2011). Proses Penyelesaian Sengketa Konsumen; di Tinjau dari Hukum Acara Serta Kendala Implementasinya. Kencana Prenada Media Group, Jakarta.

Satriya, D. B. (2019). Praktik Jual Beli Olahan Masakan Rica-Rica Daging Anjing Di Tinjau Dari Hukum Islam Dan Etika Bisnis Islam (Studi Kasus di Warung Rica-rica P. Keprek Kelurahan Bago, Kecamatan Tulungagung, Kabupaten Tulungagung). IAIN Tulungagung.

Soesilo, R. (2013). Buku Teks Kitab undang-undang hukum pidana (KUHP) serta komentarkomentarnya lengkap pasal demi pasal. Politeia, Bogor.

Susanti, Dyah. O. (2021). Halal Characteristics of Small and Medium Micro Business Products (MSMEs) In Patemon Villag Krejengan Sub-District Probolinggo District. Journal Equity of Law and Governance, Vol 1(1).

Thabrani, A. M. (2013). Esensi Ta'abbud Dalam Konsumsi Pangan (Telaah Kontemplatif atas Makna Halâl-Thayyib). Jurnal Al-Ihkam, 8(1).

Triasih, D., Heryanti, B. R., \& Kridasaksana, D. (2016). Kajian Tentang Perlindungan Hukumbagi Konsumen Terhadap Produk Makanan Bersertifikat Halal. Jurnal Dinamika Sosial Budaya, Vol.18(2).

Widjaja, G., \& Yani, A. (2003). Hukum tentang perlindungan konsumen. Gramedia Pustaka Utama, Jakarta. 